\title{
ANALISIS DAN PERANCANGAN ENTERPRISE ARCHITECTURE DIREKTORAT METROLOGI PADA FUNGSI PERENCANAAN DAN OPERASIONAL MENGGUNAKAN FRAMEWORK TOGAF ADM
}

\section{ANALYSIS AND DESIGN OF ENTERPRISE ARCHITECTURE DIRECTORATE OF METROLOGY IN PLANNING AND OPERATIONAL FUNCTIONS USING TOGAF ADM FRAMEWORK}

\author{
${ }^{1}$ Nabila Mutiara, ${ }^{2}$ Rachmadita Andreswari, ${ }^{3}$ Ridha Hanafi \\ ${ }^{1,2,3}$ Program Studi Sistem Informasi, Fakultas Rekayasa Industri, Telkom University \\ 'nabilamutiaraaa@gmail.com, ${ }^{2}$ andreswari@gmail.com, ${ }^{3}$ ridhanafi@gmail.com
}

\begin{abstract}
Abstrak- Direktorat Metrologi merupakan salah satu instansi pemerintahan yang memiliki fokus memberikan pelayanan jasa pengukuran terhadap alat ukur, takar, timbang dan perlengkapannya (UTTP). Dalam menjalankan tugas pokok yang tertera pada Peraturan Menteri Perdagangan Republik Indonesia (PERMENDAGRI) nomor 8/M-DAG/PER/2/2016 tentang Organisasi dan Tata Kerja Kementrian Perdagangan. Direktorat Metrologi memiliki kegiatan utama yang dijalankan yaitu pelayanan perizinan dan non perizinan untuk meningkatkan citra pasar tradisional melalui kebenaran hasil pengukuran. Adanya proses bisnis yang kompleks pada aktivitas bisnis tersebut menjadi alasan perlunya pemanfaatan teknologi informasi guna menunjang kebutuhan bisnis. Dalam hal ini, untuk memenuhi kebutuhan tersebut diperlukan keselarasan antara teknologi informasi dengan kebutuhan bisnis dari Direktorat Metrologi, sehingga dibutuhkan sebuah perancangan enterprise architecture dengan metode TOGAF ADM framework yang digunakan sebagai panduan dalam pembuatan perancangan tersebut. Pembuatan rancangan enterprise architecture ini terdiri dari beberapa fase yang harus dijalankan, antara lain preliminary phase, architecture vision phase, business architecture phase, information system phase, dan technology architecture phase. Dalam penelitian ini akan dibahas strategi bisnis dan strategi teknologi informasi pada fungsi perencanaan dan operasional Direktorat Metrologi. Hasil dari penelitian ini berupa blueprint dari arsitektur bisnis dan teknologi informasi saat ini serta usulan/rekomendasi dalam melaksanakan perbaikan terutama pada fungsi perencanaan dan operasional yang dapat dijadikan acuan dalam pembuatan perencanaan strategis sistem informasi pada Direktorat Metrologi.
\end{abstract}

Kata kunci: Enterprise architecture, TOGAF ADM framework, Direktorat Metrologi, Blueprint, Perencanaan strategis, Teknologi informasi.

\footnotetext{
Abstract-Directorate of Metrology is one of government agencies that has focused provide services measurement of UTTP instrument. In carrying out the main task stipulated on Trade Minister Regulation of Indonesia number 8/M-DAG/PER/2016 about Organization and Working Procedures of Trades Ministry that implementation the formulation, implementation and control policy, the guidelines, the norm, standard, procedures and criteria, as well as providing technical guidance and evaluation of policy
}

implementation in the field of metrology, The Directorate of Metrology's main activities are licensing and nonlicensing services to improve traditional market image by the verifiable measurement results. The complexity of business processes is the reason for the necessity of utilizing information technology to support business needs. In order to align the aspect of business and information technology, it is necessary to design the enterprise architecture using TOGAF ADM framework as guidelines. Designing enterprise architecture consists several phase, there are preliminary phase, architecture vision phase, business architecture phase, information system phase, dan technology architecture phase. This research will be discussed about business and information technology strategy of planning and operational function in Directorate of Metrology. The output of this research is blueprint business and information technology architecture baseline and target recommendation to improvement about information technology of planning and operational functions in Directorate of Metrology that can be used as reference for making strategic planning of system information in Metrology Directorate.

Keywords: Enterprise architecture, TOGAF ADM framework, Directorate Metrology, Blueprint, Strategic Planning, Information technology.

\section{PENDAHULUAN}

Perkembangan teknologi informasi pada saat ini mendorong berbagai aspek masyarakat untuk melakukan pengembangan terutama di bidang teknologi informasi, terutama bagi organiasasi atau perusahaan. Pemanfaatan teknologi dalam melakukan perencanaan serta pengelolaan sistem informasi yang baik pada perusahaan sehingga dapat meningkatkan kinerja proses bisnis serta dapat meningkatkan kualitas serta daya saing bisnis. Dalam menerapkan teknologi infomasi tersebut dibutuhkan penyelarasan antara strategi bisnis dan sistem informasi yang tepat sehingga dapat membantu organisasi dalam merealisasikan tujuan strategisnya [1]. Pada penelitian ini menjelaskan mengenai penyelarasan strategi bisnis dan sistem informasi pada Direktorat Metrologi. 
Direktorat Metrologi merupakan salah satu instansi pemerintahan yang berfokus pada pelayanan jasa pengukuran terhadap alat ukur, takar, timbang dan perlengkapannya (UTTP). Berdasarkan Peraturan Menteri Perdagangan Republik Indonesia (PERMENDAGRI) nomor 8/M-DAG/PER/2/2016 tentang Organisasi dan Tata Kerja Kementrian Perdagangan. Dalam mendukung pelaksanaan tugas pokok tersebut, terdapat beberapa aktivitas utama yang dijalankan oleh Direktorat Metrologi guna meningkatkan citra pasar tradisional melalui kebenaran hasil pengukuran, yaitu pelayanan perizinan dan pelayanan non perizinan. Pelayanan perizinan, meliputi perizinan untuk memproduksi atau merakit serta memperbaiki alat-alat ukur, takar, timbang dan perlengkapannya (UTTP) serta melakukan import atau memasukkan alat UTTP ke wilayah Republik Indonesia. Setiap perusahaan pembuat alat UTTP wajib memiliki surat izin tanda pabrik yang diterbitkan oleh Direktorat Jendral Perdagangan Dalam Negeri Direktur Mterologi sebagaimana diatur dalam SK Menteri Perindustrian dan Perdagangan No. 61/MPP/Kep/2/1998 dan No. 251/MPP/Kep/6/1999 tentang Penyelenggaraan Kemetrologian [3].

Adapun pelayanan non perizinan meliputi pelayanan kalibrasi dan tera/tera ulang pada alat UTTP yang beredar di masyarakat. Dalam hal ini, kompleksitas proses bisnis yang dijalankan memerlukan pemanfaatan TI guna membantu keberlangsungan aktivitas bisnis yang dijalankan. Direktorat Metrologi telah menerapkan pemanfaatan TI, namun penggunaan TI tersebut masih belum maksimal karena penggunaan system informasi tersebut hanya pada beberapa fungsi bisnis belum mencakup keseluruhan kebutuhan bisnis dari Direktorat Metrologi. Adapun penggunaan aplikasi hanya terdapat pada fungsi pelayanan pelanggan guna merekam data dan order dari pelanggan secara onsite. Pada fungsi operasional terdapat sistem informasi yang ada digunakan hanya mengakomodasi aktivitas penerbitan izin/ izin tipe, sedangkan aktivitas operasional yang lainnya masih dilakukan secara manual. Sistem informasi yang ada saat ini belum mampu memenuhi kebutuhan infomasi secara keseluruhan, sehingga pelayanan yang diberikan belum dilakukan secara maksimal baik dari segi waktu, maupun pemanfaatan sumber daya.

Berdasarkan permasalahan tersebut dibutuhkan adanya pemanfaatan teknologi informasi yang dapat mencakup kebutuhan keseluruhan aktivitas bisnis dan saling terkait satu dengan yang lainnya sehingga dapat terpenuhinya kebutuhan informasi guna menunjang keberlangsungan kegiatan bisnis yang dijalankan oleh Direktorat Metrologi. Dalam hal ini, dibutuhkan adanya keselarasan antara strategi bisnis dan teknologi informasi guna menerapkan sistem informasi yang dapat meningkatkan performa kinerja dalam mendukung keberlangsungan aktivitas terutama pada fungsi perencanaan dan operasional Direktorat Metrologi. Enterprise architecture merupakan dasar terbaik bagi organisasi untuk menggambarkan strategi bisnis dan pengembangannya melalui TI [4]. Dalam hal ini, perancangan enterprise architecture sangat tepat digunakan untuk membantu dalam mewujudkan keselarasan antara strategi bisnis dan teknologi informasi yang dibutuhkan oleh Direktorat Metrologi, serta diimplementasikan dengan penggunaan metode TOGAF ADM framework sebagai acuan dalam pembuatan rancangan tersebut. Pemilihan TOGAF ADM didasarkan pada beberapa kriteria untuk merancang enterprise architecture, yang pertama karena adanya requirement management yang tidak dimiliki oleh framework arsitektur enterprise lainya. Requirement management sangat berguna untuk menentukan kebutuhan atau requirement dari suatu enterprise yang dijadikan sebagai input dari setiap fase pada TOGAF ADM dalam menentukan arsitektur target [5]. Pada TOGAF ADM framework terdapat beberapa fase yang digunakan, yaitu preliminary phase, architecture vision phase, business architecture phase, information system phase, dan technology architecture phase sehingga pengimplementasian enterprise architecture dapat lebih terstruktur. Hasil dari perancangan enterprise architecture ini berupa blueprint dari arsitektur bisnis dan teknologi informasi saat ini serta usulan/rekomendasi dalam melaksanakan perbaikan terutama pada fungsi perencanaan dan operasional yang dapat dijadikan acuan dalam pembuatan perencanaan strategis sistem informasi pada Direktorat Metrologi.

\section{STUDILITERATUR}

\section{A. Enterprise Architecture}

Enterprise architecture merupakan suatu hasil rancangan untuk mendeskripsikan misi stakeholder yang meliputi informasi, lokasi, organisasi dan parameter kerja, serta menjelaskan rencana untuk membangun atau mengatur sistem yang disusun guna menggambarkan keadaan perusahaan sekarang, masa depan dan kemungkinan untuk melakukan perubahan sehingga terciptanya sebuah keselarasan antara bisnis dan teknologi informasi yang dapat meningkatkan kinerja perusahaan dalam mencapai tujuan dan strategi bisnisnya [6]. Enterprise architecture memberikan pengetahuan dan dukungan dalam pengambilan keputusan pada organisasi dan dapat menjadi blueprint atas situasi saat ini dan strategi ke depan dari organisasi [7].

\section{B. TOGAF ADM Framework}

The Open Group Architecture Framework (TOGAF) merupakan salah satu kerangka kerja enterprise architecture yang memberikan metode detail bagaimana membangun dan mengelola serta mengimplementasikan enterprise architecture dan sistem informasi yang disebut Architecture Development Method (ADM) [8]. ADM merupakan metode generik yang berisikan sekumpulan aktivitas yang digunakan dalam memodelkan pengembangan arsitketur enterprise. Metode ini juga bisa digunakan sebagai panduan atau alat untuk merencanakan, merancang, mengembangkan dan mengimplementasikan arsitektur sistem informasi untuk organisasi [9]. TOGAF ADM merupakan framework yang tepat digunakan untuk mendukung perancangan enterprise architecture karena memiliki karakteristik yang sesuai dengan permasalah yang terdapat pada Direktorat Metrologi. Adapun karakteristik dari TOGAF ADM, antara lain open source, fokus pada siklus implementasi (ADM), pendekatannya bersifat menyeluruh memiliki tools untuk perencanaan dan proses yang lengkap [10]. Adapun yang harus diperhatikan oleh enterprise architect dalam menentukan beberapa fitur dari metodologi TOGAF ini, antara lain: level of details, breadth of coverage, dan extend of time horizon due to ADM [11].

\section{METODOLOGI PENELITIAN}

Model konseptual merupakan gambaran rancangan terstruktur yang menggambarkan hubungan antar konsep dalam menyelesaikan suatu masalah, serta digunakan untuk menghasilkan output sesuai dengan tujuan dari suatu penelitian. Model konseptual pada 
penelitian ini dijelaskan pada Gambar 1. Adapun tahapan-tahapan yang digunakan dalam penelitian ini, terdiri dari beberapa tahapan, antara lain: tahap persiapan, tahap identifikasi, tahap analisis \& perancangan dan tahap pelaporan.

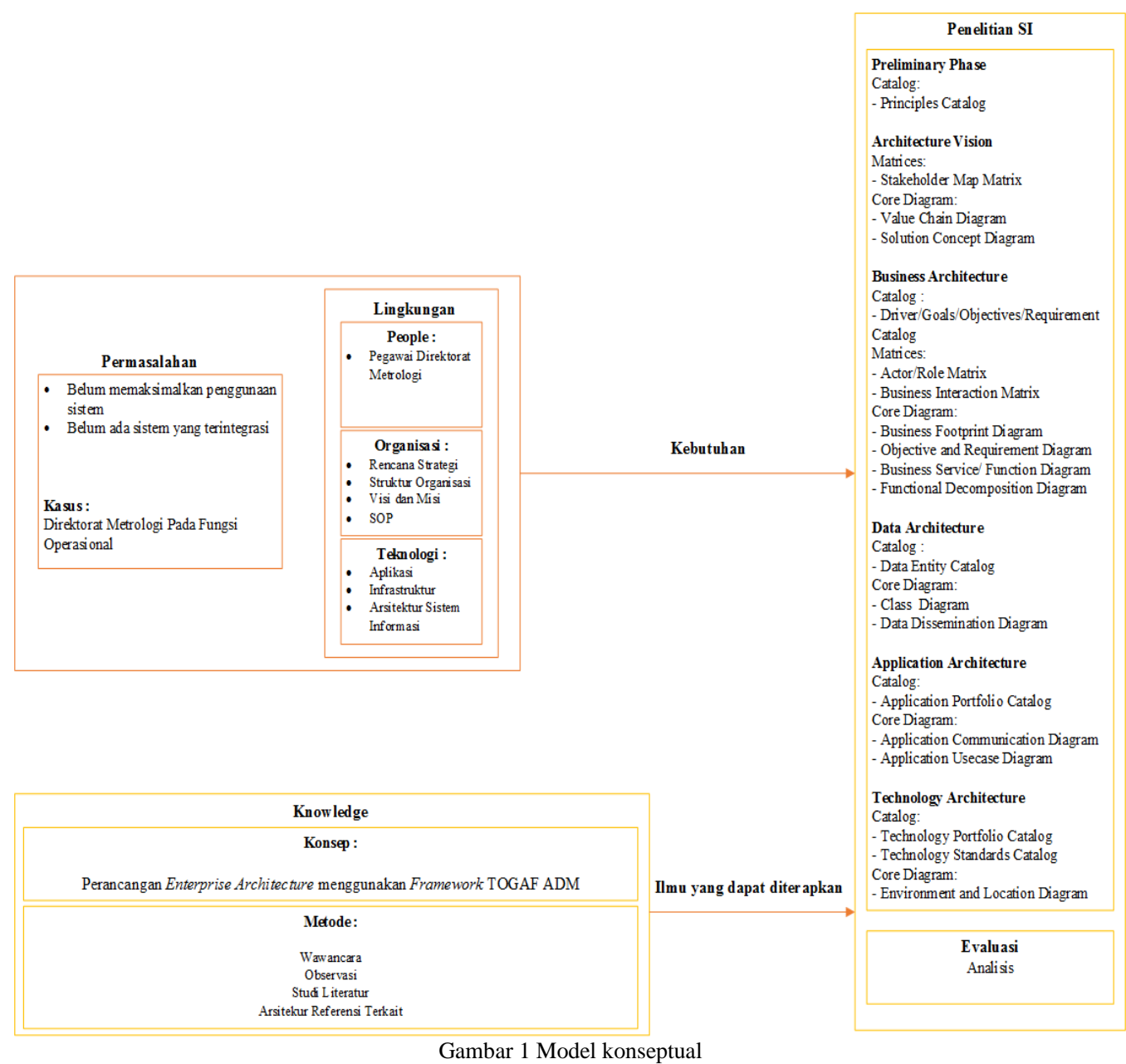

\section{HASIL DAN ANALISIS}

\section{A. Preliminary Phase}

Pada fase ini menggambarkan persiapan dalam melakukan perancangan. Fase preliminary akan menentukan bagaimana perancangan enterprise architecture akan dibuat dan dilaksanakan, serta berisi mengenai prinsip-prinsip arsitektur yang sesuai dengan kebutuhan Direktorat Metrologi yang menggambarkan karakteristik enterprise architecture. Fase preliminary digambarkan dengan principle catalog, yang merupakan daftar berisi prinsip-prinsip yang berkaitan dengan arsitektur bisnis, data, aplikasi serta teknologi yang digunakan sebagai acuan dalam melakukan perancangan. Berikut Tabel I merupakan prinsip-prinsip Direktorat Metrologi berdasarkan TOGAF ADM.
TABEL I

PRINCIPLE CATALOG

\begin{tabular}{|l|l|}
\hline \multicolumn{1}{|c|}{ Arsitektur } & \multicolumn{1}{c|}{ Prinsip } \\
\hline \multirow{4}{*}{ Business Architecture } & Keberlangsungan bisnis \\
\cline { 2 - 2 } & Peningkatan tertib ukur \\
\cline { 2 - 2 } & Kepatuhan hukum \\
\cline { 2 - 2 } & Berorientasi layanan \\
\hline \multirow{5}{*}{ Data Architecture } & Sharing data \\
\cline { 2 - 2 } & Asset data \\
\cline { 2 - 2 } & Keamanan data \\
\cline { 2 - 2 } & Akurasi data \\
\cline { 2 - 2 } & Data terpercaya \\
\hline \multirow{4}{*}{ Application Architecture } & Kemudahan penggunaan \\
\cline { 2 - 2 } & Integrasi aplikasi \\
\cline { 2 - 2 } & Ketersediaan aplikasi \\
\cline { 2 - 2 } & Hak akses penggunaan \\
\hline \multirow{5}{*}{} & Perubahan teknologi sesuai kebutuhan \\
\cline { 2 - 2 } & Kemanan teknologi \\
\cline { 2 - 2 } & Teknologi sesuai standar \\
\cline { 2 - 2 } & Kontrol teknis \\
\hline
\end{tabular}

Analisis dan Perancangan Enterprise Architecture Direktorat

Pada Fungsi Perencanaan dan Operasional Menggunakan Framework TOGAF ADM Nabila Mutiara, Rachmadita Andreswari, Ridha Hanafi (hal.22 - 30) 


\section{B. Architecture Vision}

Fase architecture vision merupakan tahap awal dalam melakukan perancangan enterprise architecture berdasarkan framework TOGAF ADM. Pada fase ini akan digambarkan value chain yang terdiri dari fungsi-fungsi yang menjalankan aktivitas utama dan pendukung yang terdapat pada Direktorat Metrologi. Gambar 3 merupakan value chain diagram pada Direktorat Metrologi.

Selain itu, pada fase ini juga digambarkan aplikasi yang akan dibuat melalui solution concept diagram. Dalam hal ini, aplikasi yang dibangun dapat diakses melalui channel internet yang digunakan oleh pengguna yang berada diluar jaringan Direktorat Metrologi dan intranet yang dapat digunakan oleh pengguna yang mengakses aplikasi melalui jaringan Direktorat Metrologi. Website digunakan sebagai interface saat pengguna mengakses aplikasi, yang terdiri dari beberapa aplikasi yang digambarkan pada mid office. Pada Back office terdapat reporting sebagai pengelola aplikasi tersebut. Gambar 4 merupakan gambaran dari solution concept diagram.

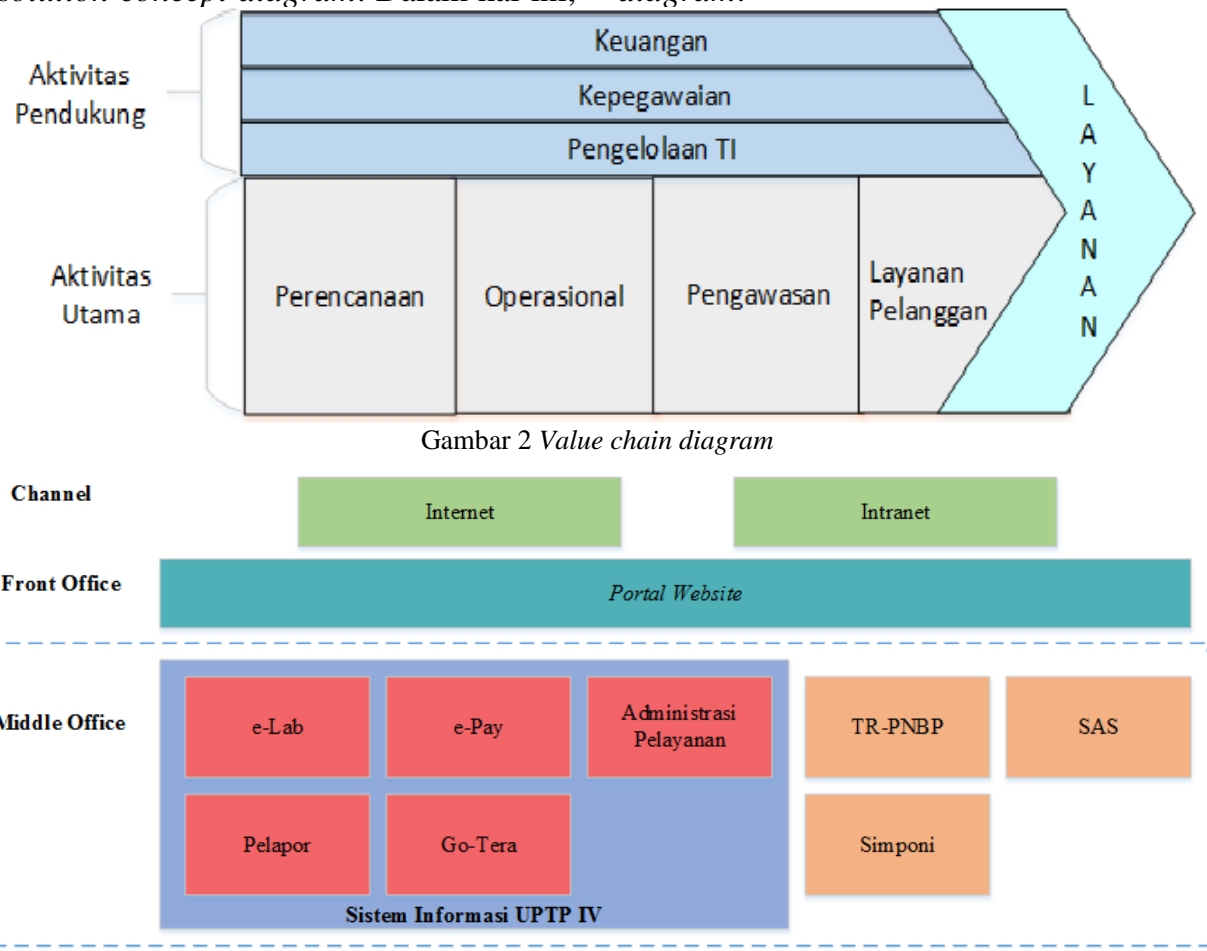

Back Office

Reporting

Gambar 3 Solution concept diagram

\section{Business Architecture}

Pada fase business architecture ini berisi target dari bisnis arsitektur organisasi/perusahaan yang dirancang setelah dilakukan analisis dan perbaikan dari bisnis arsitektur baseline. Untuk mendukung pembuatan target tersebut di definisikan terlebih dahulu strategi bisnis, pengelolaan, organisasi dan proses bisnis utama. Tujuan dari fase ini agar organisasi/perusahaan dapat menentukan perbaikan pada aktivitas bisnis yang diharapkan dapat mendukung tercapainya strategi bisnis yang telah ditentukan.

\section{Driver/Goals/Objectives Catalog}

Pada Tabel II menjelaskan mengenai driver, goals dan objectives terkait dengan fungsi perencanaan dan operasional yang terdapat pada Direktorat Metrologi.
TABEL II

DRIVER/GOALS/OBJECTIVES CATALOG

\begin{tabular}{|l|}
\hline \multicolumn{1}{|c|}{ Driver } \\
\hline $\begin{array}{l}\text { Menciptakan perdagangan dalam negeri yang tumbuh dan } \\
\text { berkualitas }\end{array}$ \\
\hline \multicolumn{1}{|c|}{ Objectives } \\
\hline Peningkatan tertib ukur \\
\hline Peningkatan layanan kalibrasi \\
\hline \multicolumn{1}{|c|}{} \\
\hline Mengelola sistem perencanaan kerja yang jelas dan terstruktur \\
\hline $\begin{array}{l}\text { Menambah jumlah rumusan peraturan teknis metrologi legal } \\
\text { sesuai kebutuhan }\end{array}$ \\
\hline $\begin{array}{l}\text { Peningkatan jumlah alat standar yang tertelusur secara nasional } \\
\text { dan internasional. }\end{array}$ \\
\hline Meningkatkan jumlah sertifikat yang diterbitkan \\
\hline Mempertahankan jumlah layanan kalibrasi yang terkait akreditasi \\
\hline Peningkatan daerah tertib ukur \\
\hline Peningkatan pasar tertib ukur \\
\hline Meningkatnya jumlah alat UTTP dan BDKT yang diawasi. \\
\hline Meningkatkan jumlah publikasi yang dilaksanakan. \\
\hline
\end{tabular}


2. Business Service/Business Process Matrix Baseline

Berikut Tabel III berisi keterkaitan antara business service dan business process baseline yang terdapat pada fungsi perencanaan dan operasional Direktorat Metrologi.

TABEL III

\begin{tabular}{|c|c|}
\hline \multicolumn{2}{|c|}{ BUSINESS SERVICE/BUSINESS PROCESS MATRIX EXISTING } \\
\hline Business Service & Business Process \\
\hline \multicolumn{2}{|r|}{ Perencanaan } \\
\hline $\begin{array}{l}\text { Pengelolaan rencana } \\
\text { dan anggaran kerja }\end{array}$ & $\begin{array}{l}\text { Penyusunan rencana kegiatan dan } \\
\text { anggaran kerja }\end{array}$ \\
\hline $\begin{array}{l}\text { Perumusan kebijakan } \\
\text { kemetrologian }\end{array}$ & $\begin{array}{l}\text { Perumusan peraturan teknis } \\
\text { pelaksanaan metrologi legal }\end{array}$ \\
\hline \multicolumn{2}{|r|}{ Operasional } \\
\hline \multirow[t]{2}{*}{ Pengujian alat UTTP } & Pelaksanaan pengujian tera/ tera ulang \\
\hline & Pelaksanaan pengujian kalibrasi \\
\hline \multirow[t]{4}{*}{ Penerbitan perizinan } & Pelaksanaan penerbitan izin tipe onsite \\
\hline & Pelaksanaan penerbitan izin tipe online \\
\hline & $\begin{array}{l}\text { Pelaksanaan penerbitan izin tanda } \\
\text { pabrik onsite }\end{array}$ \\
\hline & $\begin{array}{l}\text { Pelaksanaan penerbitan izin tanda } \\
\text { pabrik online }\end{array}$ \\
\hline $\begin{array}{l}\text { Pengawasan alat } \\
\text { UTTP/BDKT }\end{array}$ & $\begin{array}{l}\text { Pelaksanaan pengawasan alat } \\
\text { UTTP/BDKT }\end{array}$ \\
\hline
\end{tabular}

3. Business Service/Business Process Matrix Target

Berikut Tabel IV berisi keterkaitan antara business service dan business process target yang terdapat pada fungsi perencanaan dan operasional Direktorat Metrologi.

TABEL IV

BUSINESS SERVICE/BUSINESS PROCESS MATRIX TARGET

\begin{tabular}{|c|c|}
\hline Business Service & Business Process \\
\hline \multicolumn{2}{|r|}{ Perencanaan } \\
\hline $\begin{array}{l}\text { Pengelolaan rencana dan } \\
\text { anggaran kerja }\end{array}$ & $\begin{array}{l}\text { Penyusunan rencana kegiatan dan } \\
\text { anggaran kerja }\end{array}$ \\
\hline $\begin{array}{l}\text { Perumusan kebijakan } \\
\text { kemetrologian }\end{array}$ & $\begin{array}{l}\text { Perumusan peraturan teknis } \\
\text { pelaksanaan metrologi legal }\end{array}$ \\
\hline \multicolumn{2}{|r|}{ Operasional } \\
\hline \multirow[t]{2}{*}{ Pengujian alat UTTP } & Pelaksanaan pengujian tera/ tera ulang \\
\hline & Pelaksanaan pengujian kalibrasi \\
\hline \multirow[t]{2}{*}{ Penerbitan perizinan } & Pelaksanaan penerbitan izin tipe \\
\hline & $\begin{array}{l}\text { Pelaksanaan penerbitan izin tanda } \\
\text { pabrik }\end{array}$ \\
\hline $\begin{array}{l}\text { Pengawasan alat } \\
\text { UTTP/BDKT }\end{array}$ & $\begin{array}{l}\text { Pelaksanaan pengawasan alat } \\
\text { UTTP/BDKT }\end{array}$ \\
\hline
\end{tabular}

D. Information System Architecture

Pada fase information system architecture ini mendefinisikan dua area besar dalam sebuah sistem informasi, yaitu data dan aplikasi. Pada fase ini berisi perancangan data dan aplikasi pada fungsi perencanaan dan operasional pada Direktorat Metrologi.

\section{Information System Architecture Baseline}

Pada fase information system architecture baseline menjelaskan mengenai data dan aplikasi yang digunakan saat

\section{6}

Metrologi ini. Dalam hal ini, aplikasi yang digunakan saat ini terdapat pada fungsi operasional berupa website SPPK. Website ini mengakomodasi kegiatan operasional dalam melakukan proses bisnis penerbitan izin tipe dan izin tanda pabrik. Dalam hal ini, pendaftaran untuk izin tipe dan tanda pabrik dapat dilakukan online, kegiatan validasi dan verifikasi dokumen permohonan perizinan hingga penerbitan izin tersebut dilakukan melalui sistem. Namun, untuk data tidak dapat diidentifikasi karena peneliti tidak dapat melihat ke dalam aplikasi tersebut.

\section{Information System Architecture Target}

Pada fase information system architecture target menjelaskan mengenai data dan aplikasi yang diusulkan terkait fungsi perencanaan dan operasional Direktorat Metrologi. Adapun aplikasi yang diusulkan akan dijelaskan pada Tabel V dibawah ini.

Berdasarkan application service diatas, setiap aplikasi terdiri dari beberapa entitas data yang terkait. Hubungan antara aplikasi dan entitas data tersebut digambarkan pada data dissemination diagram yang dibagi berdasarkan fungsi perencanaan dan operasional, seperti pada Gambar 5 dan Gambar 6.

TABEL V APPLICATION SERVICE TARGET

\begin{tabular}{|c|l|}
\hline No & \multicolumn{1}{|c|}{ Application service } \\
\hline 1 & Pengelolaan Data Pengujian \\
\hline 2 & Pengelolaan Hasil Pengujian \\
\hline 3 & Pengelolaan Laporan Pengujian \\
\hline 4 & Pengelolaan Laboratorium \\
\hline 5 & Pengelolaan Laporan Monitoring Laboratorium \\
\hline 6 & Pengelolaan Data Serah Terima Alat UTTP \\
\hline 7 & Pengelolaan Data Perizinan \\
\hline 8 & Pengelolaan Hasil Perizinan \\
\hline 9 & Pengelolaan Laporan Perizinan \\
\hline 10 & Pengelolaan Keluhan \\
\hline 11 & Pengelolaan Laporan Keluhan \\
\hline 12 & Pengelolaan Perencanaan Kerja \\
\hline 13 & Pengelolaan History Perencanaan Kerja \\
\hline 14 & Pengelolaan Laporan Peraturan Kemetrologian \\
\hline 15 & Pengelolaan Data User \\
\hline
\end{tabular}

E. Technology Architecture

Pada fase technology architecture menjelasakan mengenai arsitektur teknologi yang meliputi infrastruktur teknologi berupa software maupun hardware yang digunakan untuk mendukung pengimplementasian arsitektur sistem informasi pada suatu perusahaan.

\section{Technology Architecture Baseline}

Kondisi arsitektur teknologi Direktorat Metrologi saat ini digambarkan pada artifak environment and location diagram pada Gambar 7. Adapun hubungan komponen teknologi yang terdapat pada Direktorat Metrologi dan aplikasi yang digunakan saat ini dijelaskan pada Tabel application/technology matrix baseline berikut ini.

\section{Analisis dan Perancangan Enterprise Architecture Direktorat}

Pada Fungsi Perencanaan dan Operasional Menggunakan Framework TOGAF ADM Nabila Mutiara, Rachmadita Andreswari, Ridha Hanafi (hal.22 - 30) 
TABEL VI

APPLICATION/TECHNOLOGY MATRIX BASELINE

\begin{tabular}{|c|c|l|}
\hline No & Aplikasi & \multicolumn{1}{|c|}{ Technology Component } \\
\hline 1 & Website SPPK & $\begin{array}{l}\text { Server website SPPK, Switch distribution, } \\
\text { web server, database, Switch lantai 3, } \\
\text { UPS, Internet, dan VPN. }\end{array}$ \\
\hline 2 & Loket PSP & $\begin{array}{l}\text { Server aplikasi PSP, Switch distribution, } \\
\text { Switch lantai 1, database, dan VPN. }\end{array}$ \\
\hline 3 & Kasir/Pembayaran & $\begin{array}{l}\text { Server aplikasi PSP, Switch distribution, } \\
\text { Switch lantai 1, database, dan VPN. }\end{array}$ \\
\hline
\end{tabular}

2. Technology Architecture Target

Arsitektur teknologi yang diusulkan berupa penambahan database server dan perubahan fungsi pada beberapa server. Berikut ini merupakan gambaran dari environment and location diagram target pada Direktorat Metrologi.

Selain itu, untuk mendukung penggunaan usulan aplikasi terdapat beberapa perubahan dan penambahan pada technology component. Tabel VII dibawah ini berisi penjelasan mengenai keterkaitan antara aplikasi dan komponen teknologi yang diusulkan pada Direktorat Metrologi.

TABEL VII

APPLICATION/TECHNOLOGY MATRIX BASELINE

\begin{tabular}{|c|c|c|c|}
\hline No & Aplikasi & $\begin{array}{c}\text { Logical Application } \\
\text { Component }\end{array}$ & $\begin{array}{l}\text { Technology } \\
\text { Component }\end{array}$ \\
\hline \multirow{8}{*}{1} & \multirow{8}{*}{$\begin{array}{l}\text { Website } \\
\text { UPTP IV }\end{array}$} & Pengelolaan Data Pelanggan & \multirow{8}{*}{$\begin{array}{l}\text { Server } \\
\text { website UPTP } \\
\text { IV, Server } \\
\text { Backup, } \\
\text { Switch } \\
\text { distribution, } \\
\text { Switch } \\
\text { Access, UPS, } \\
\text { Internet, } \\
\text { VPN, dan PC } \\
\text { Server. }\end{array}$} \\
\hline & & $\begin{array}{l}\text { Pengelolaan Penerimaan } \\
\text { Permohonan Perizinan }\end{array}$ & \\
\hline & & $\begin{array}{l}\text { Pengelolaan Penerimaan } \\
\text { Permohonan Pengujian }\end{array}$ & \\
\hline & & Pengelolaan Status Layanan & \\
\hline & & $\begin{array}{l}\text { Pengelolaan Data History } \\
\text { Layanan }\end{array}$ & \\
\hline & & Pengelolan Data User & \\
\hline & & Pengelolaan Keluhan & \\
\hline & & Pengelolaan Pembayaran & \\
\hline \multirow{11}{*}{2} & \multirow{11}{*}{$\begin{array}{l}\text { Administrasi } \\
\text { Layanan }\end{array}$} & Pengelolaan Data Pelanggan & \multirow{11}{*}{$\begin{array}{l}\text { Web Server } \\
\text { Aplikasi, } \\
\text { Server } \\
\text { Database } \\
\text { Aplikasi, } \\
\text { Server } \\
\text { Backup, } \\
\text { Switch } \\
\text { distribution, } \\
\text { Switch } \\
\text { access, UPS, } \\
\text { Internet, } \\
\text { VPN, dan PC } \\
\text { Server. }\end{array}$} \\
\hline & & $\begin{array}{l}\text { Pengelolaan Penerimaan } \\
\text { Permohonan Perizinan }\end{array}$ & \\
\hline & & $\begin{array}{l}\text { Pengelolaan Penerimaan } \\
\text { Permohonan Pengujian }\end{array}$ & \\
\hline & & Pengelolaan Status Layanan & \\
\hline & & $\begin{array}{ll}\text { Pengelolaan } & \text { Penyerahan } \\
\text { Hasil Pengujian } & \\
\end{array}$ & \\
\hline & & $\begin{array}{ll}\text { Pengelolaan } & \text { Penyerahan } \\
\text { Hasil Perizinan } & \\
\end{array}$ & \\
\hline & & $\begin{array}{l}\text { Pengelolaan Penyerahan Alat } \\
\text { UTTP }\end{array}$ & \\
\hline & & $\begin{array}{lll}\begin{array}{l}\text { Pengelolaan } \\
\text { Layanan }\end{array} & \text { Data } & \\
\end{array}$ & \\
\hline & & $\begin{array}{ll}\text { Pengelolaan } & \text { Laporan } \\
\text { Layanan Pengujian } & \\
\end{array}$ & \\
\hline & & $\begin{array}{ll}\text { Pengelolaan } & \text { Laporan } \\
\text { Layanan Perizinan } & \\
\end{array}$ & \\
\hline & & Pengelolan Data User & \\
\hline 3 & e-Pay & Pengelolaan Pembayaran & Server \\
\hline
\end{tabular}

\begin{tabular}{|c|c|c|c|}
\hline No & Aplikasi & $\begin{array}{c}\text { Logical Application } \\
\text { Component }\end{array}$ & $\begin{array}{l}\text { Technology } \\
\text { Component } \\
\end{array}$ \\
\hline & & $\begin{array}{l}\text { Pengelolaan Laporan } \\
\text { Transaksi Pembayaran }\end{array}$ & $\begin{array}{l}\text { Aplikasi, } \\
\text { Server }\end{array}$ \\
\hline & & Pengelolaan Data Kuitansi & Database \\
\hline & & Pengelolan Data User & $\begin{array}{l}\text { Server } \\
\text { Backup, } \\
\text { Switch } \\
\text { distribution, } \\
\text { Switch } \\
\text { access, UPS, } \\
\text { Internet, } \\
\text { VPN, dan PC } \\
\text { Server. }\end{array}$ \\
\hline \multirow{10}{*}{4} & \multirow{10}{*}{ e-Lab } & Pengelolaan Data Pengujian & \multirow{10}{*}{$\begin{array}{l}\text { Web Server } \\
\text { Aplikasi, } \\
\text { Server } \\
\text { Database } \\
\text { Aplikasi, } \\
\text { Server } \\
\text { Backup, } \\
\text { Switch } \\
\text { distribution, } \\
\text { Switch } \\
\text { access, UPS, } \\
\text { Internet, } \\
\text { VPN, dan PC } \\
\text { Server. }\end{array}$} \\
\hline & & Pengelolaan Hasil Pengujian & \\
\hline & & $\begin{array}{ll}\text { Pengelolaan } & \text { Laporan } \\
\text { Pengujian } & \\
\end{array}$ & \\
\hline & & Pengelolaan Laboratorium & \\
\hline & & $\begin{array}{l}\text { Pengelolaan Laporan } \\
\text { Monitoring Laboratorium }\end{array}$ & \\
\hline & & $\begin{array}{l}\text { Pengelolaan Data Serah } \\
\text { Terima Alat UTTP }\end{array}$ & \\
\hline & & Pengelolaan Data Perizinan & \\
\hline & & Pengelolaan Hasil Perizinan & \\
\hline & & $\begin{array}{ll}\text { Pengelolaan } & \text { Laporan } \\
\text { Perizinan } & \\
\end{array}$ & \\
\hline & & Pengelolan Data User & \\
\hline \multirow{4}{*}{5} & \multirow{4}{*}{ Go-Tera } & Pengelolaan Pengujian Insitu & \multirow{4}{*}{$\begin{array}{l}\text { Web Server } \\
\text { Aplikasi, } \\
\text { Server } \\
\text { Database } \\
\text { Aplikasi, } \\
\text { Server } \\
\text { Backup, } \\
\text { Switch } \\
\text { distribution, } \\
\text { Switch } \\
\text { access, UPS, } \\
\text { Internet, } \\
\text { VPN, dan PC } \\
\text { Server. }\end{array}$} \\
\hline & & Pengelolaan Data Penera & \\
\hline & & $\begin{array}{l}\text { Pengelolaan Data Surat } \\
\text { Perintah Tugas }\end{array}$ & \\
\hline & & Pengelolan Data User & \\
\hline \multirow{8}{*}{6} & \multirow{8}{*}{ Pelapor } & $\begin{array}{l}\text { Pengelolaan Perencanaan } \\
\text { Kerja }\end{array}$ & \multirow{8}{*}{$\begin{array}{l}\text { Web Server } \\
\text { Aplikasi, } \\
\text { Server } \\
\text { Database } \\
\text { Aplikasi, } \\
\text { Server } \\
\text { Backup, } \\
\text { Switch } \\
\text { distribution, } \\
\text { Switch } \\
\text { access, UPS, } \\
\text { Internet, } \\
\text { VPN, dan PC } \\
\text { Server. }\end{array}$} \\
\hline & & $\begin{array}{ll}\text { Pengelolaan } & \text { History } \\
\text { Perencanaan Kerja } & \\
\end{array}$ & \\
\hline & & $\begin{array}{l}\text { Pengelolaan Laporan } \\
\text { Peraturan Kemetrologian }\end{array}$ & \\
\hline & & $\begin{array}{ll}\text { Pengelolaan } & \text { Laporan } \\
\text { Bulanan } & \\
\end{array}$ & \\
\hline & & $\begin{array}{ll}\text { Pengelolaan } & \text { Laporan } \\
\text { Triwulan } & \\
\end{array}$ & \\
\hline & & Pengelolaan Laporan Kinerja & \\
\hline & & $\begin{array}{lll}\text { Pengelolaan Data History } \\
\text { Laporan }\end{array}$ & \\
\hline & & Pengelolan Data User & \\
\hline
\end{tabular}




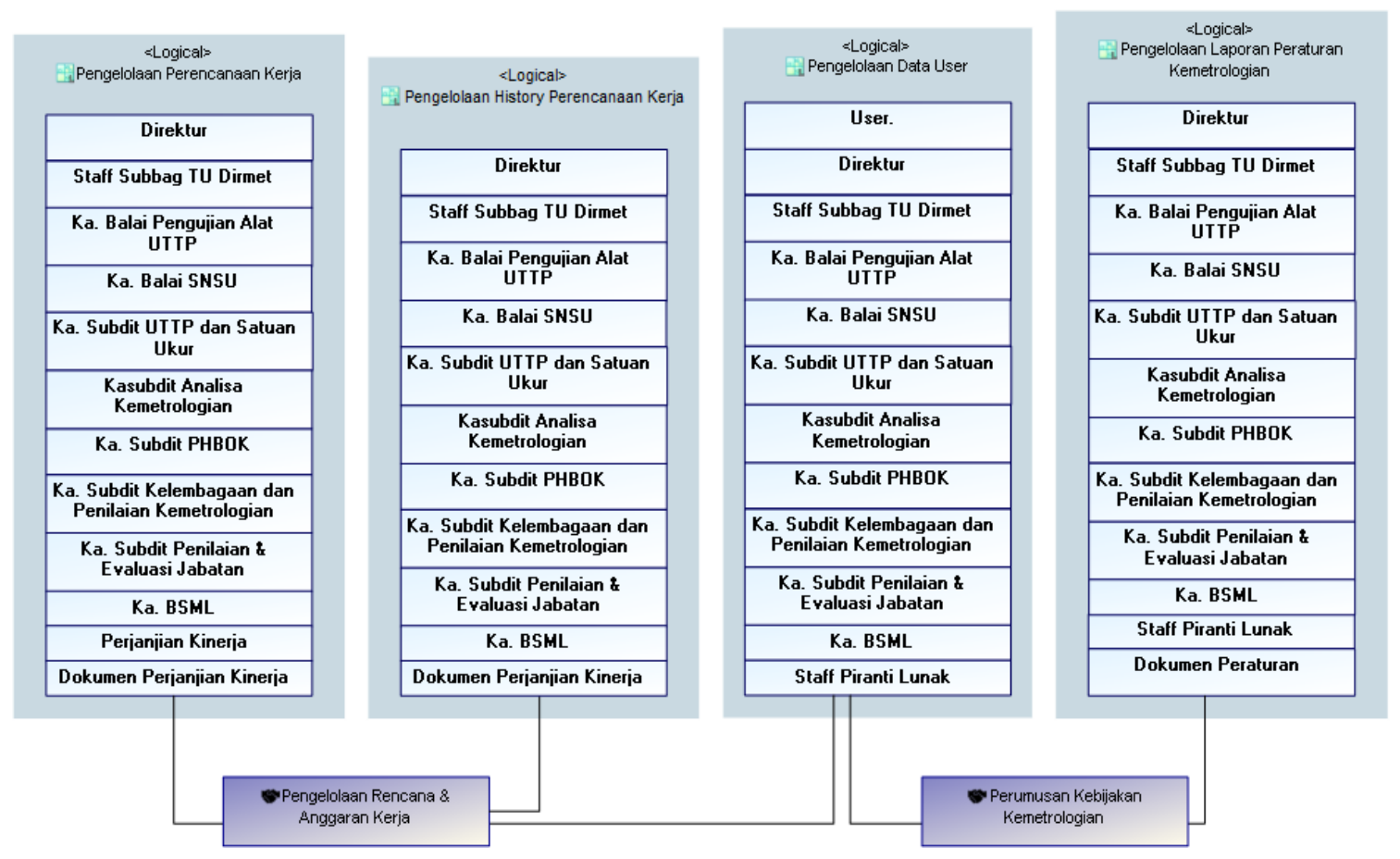

Gambar 4 Data dissemination diagram pada fungsi perencanaan

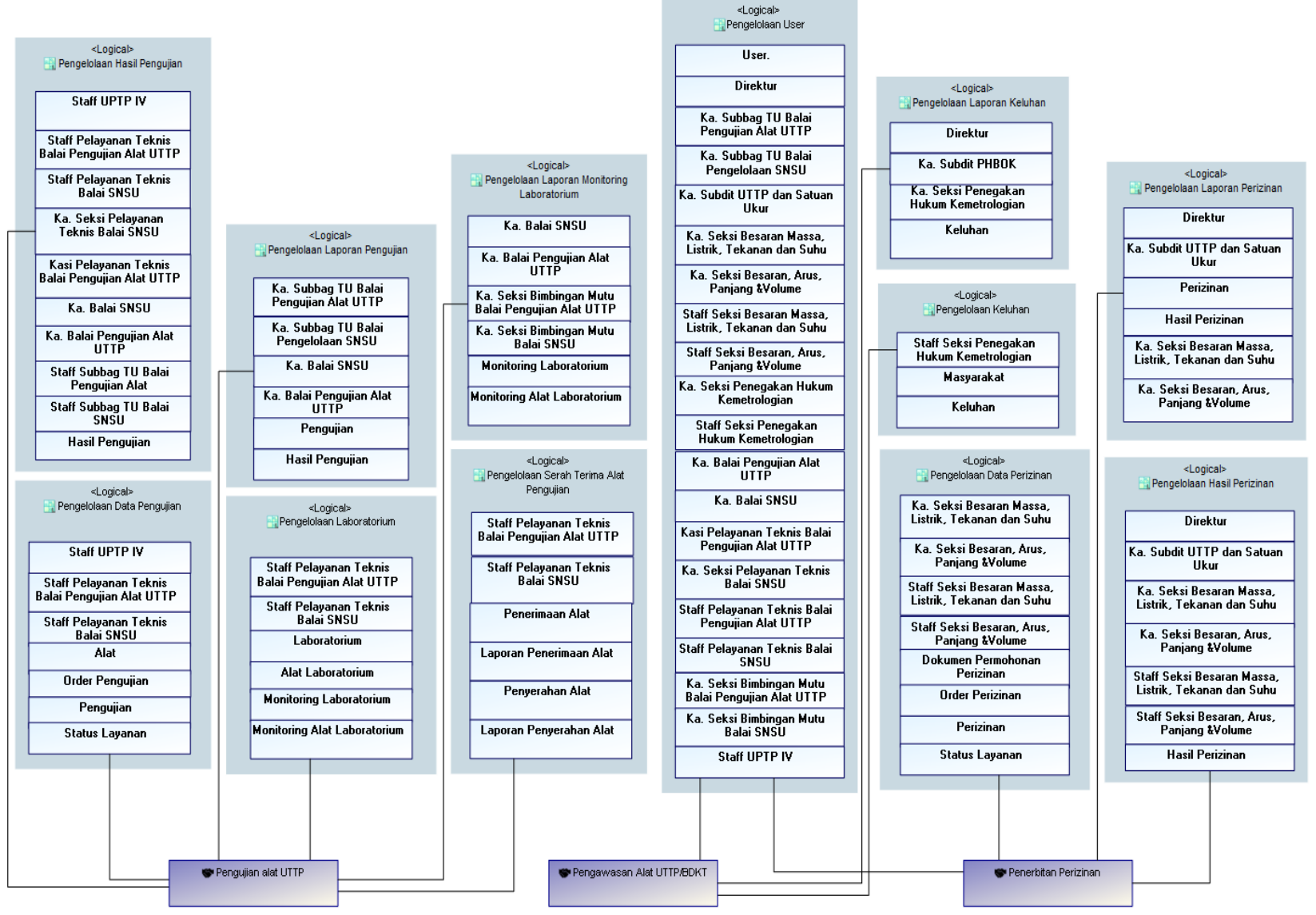

Gambar 5 Data dissemination diagram pada fungsi perencanaan

28

Metrologi
Analisis dan Perancangan Enterprise Architecture Direktorat

Pada Fungsi Perencanaan dan Operasional Menggunakan Framework TOGAF ADM Nabila Mutiara, Rachmadita Andreswari, Ridha Hanafi (hal.22 - 30) 


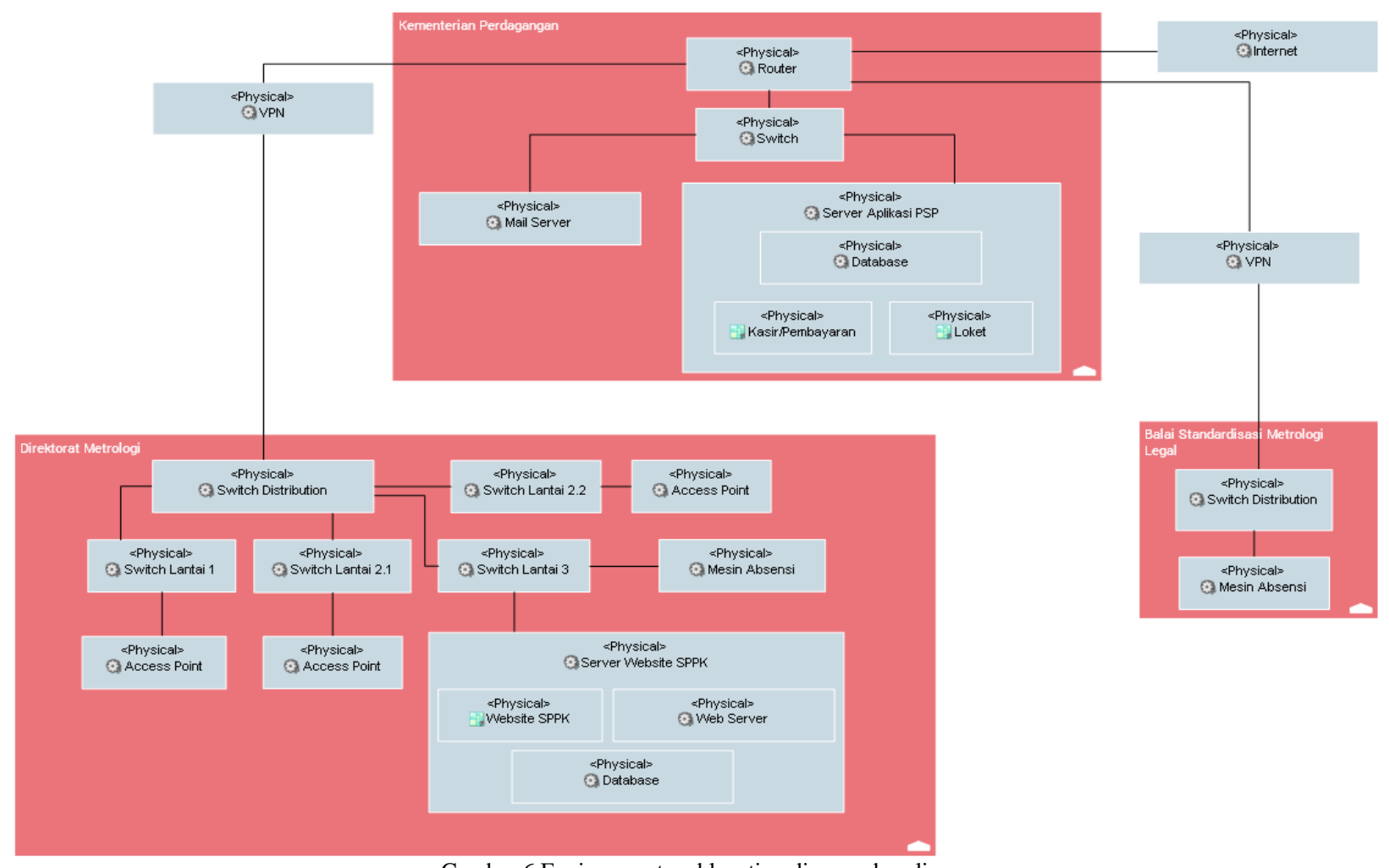

Gambar 6 Environment and location diagram baseline

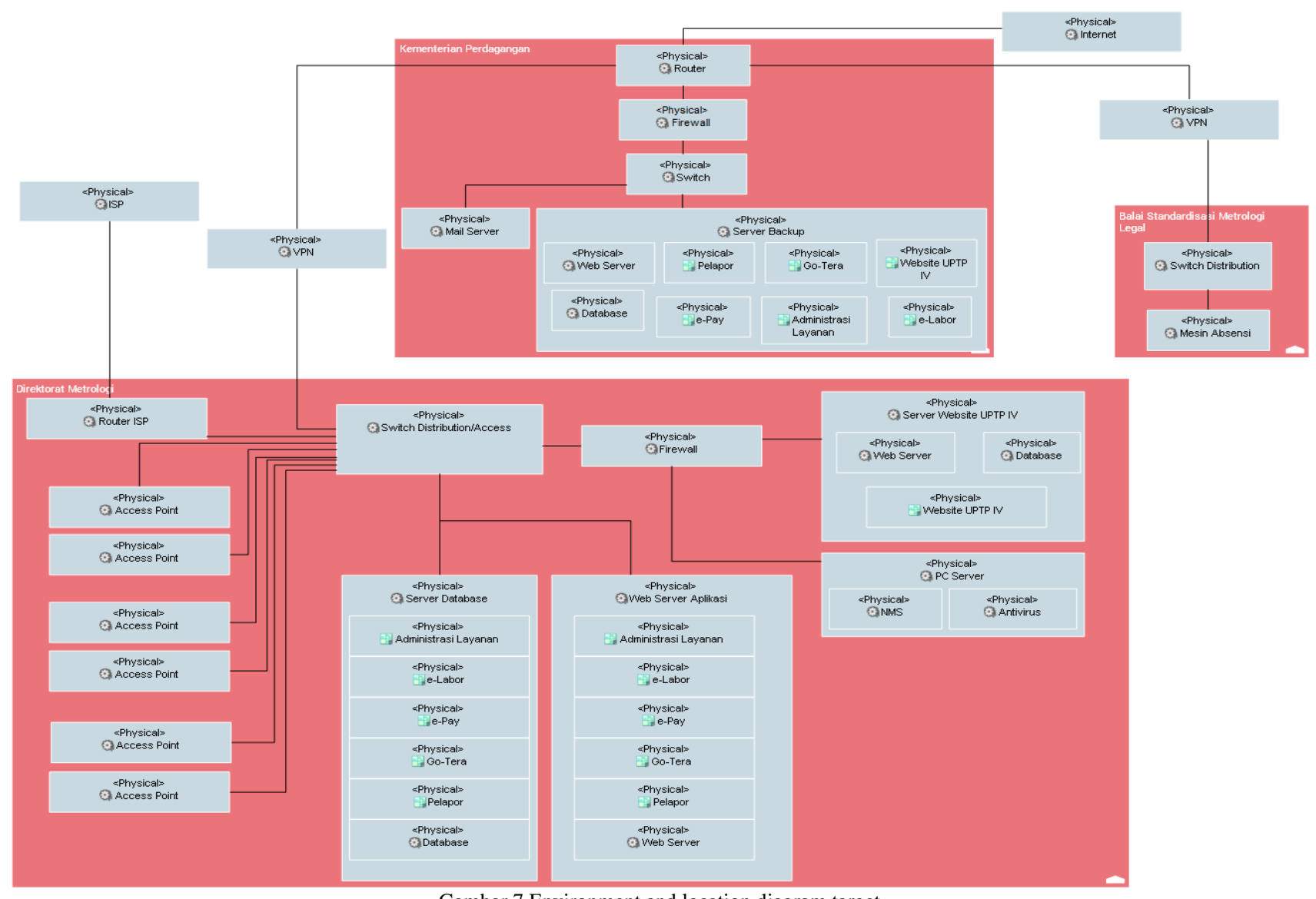

Gambar 7 Environment and location diagram target 


\section{KESIMPULAN}

Berdasarkan hasil analisis dan perancangan enterprise architecture yang dilakukan pada penelitian dapat disimpulkan bahwa, perancangan enterprise architecture berfokus pada fungsi perencanaan dan operasional Direktorat Metrologi. Metode yang digunakan sebagai acuan dalam perancangan ini adalah TOGAF ADM framework yang dilakukan hingga fase technology architecture.

Pada penelitian ini menghasilkan enterprise architecture blueprint berupa gambaran kondisi arsitektur bisnis, sistem informasi dan teknologi saat ini serta usulan perbaikan arsitektur tersebut yang dapat dijadikan acuan dalam melakukan pembuatan strategi perencanaan sistem informasi untuk mendukung keberlangsungan kegiatan bisnis agar dapat meningkatkan kinerja serta mendukung pencapaian strategi bisnis pada Direktorat Metrologi sesuai kebutuhan berdasarkan wawancara yang dilakukan kepada pihak Direktorat Metrologi yang bersangkutan.

\section{DAFTAR PUSTAKA}

[1] Santoso, B., Jatmoko., Affandi, Achmad, 2016. Model Arsitektur Enterprise Institusi Pengujian dan Kalibrasi Alat Kesehatan. Institut Teknologi Sepuluh November.Surabaya.

[2] Rifkhan, Muhammad., Darwiyanto, Eko., 2011. Perencanaan Strategi Sistem Informasi/Teknologi Informasi Menggunakan Kerangka The Open Group Architecture Framewrok (TOGAF) Architecture Development Method (ADM), Studi Kasus: Sekretariat Badan Perencanaan dan Pembangunan Daerah Provinsi Sulawesi Tengah. Telkom University. Bandung.

[3] Republik Indonesia, 2016. Peraturan Menteri Perdagangan Republik Indonesia No. 8/M-DAG/PER/2/2016 tentang Organisasi dan Tata Kerja Kementerian Perdagangan. Sekertariat Kementerian Perdagangan.Jakarta.

[4] Republik Indonesia, 1998. Keputusan Menteri Perindustrian dan Perdagangan No. 61/MPP/Kep/2/1998 tentang Penyelenggaraan Kemetrologian. Sekertariat Kementrian Perindustrian dan Perdagangan. Jakarta.

[5] Herucakra, A. G,. Fajar, Ari. dan Hanafi,Ridha., Analisis dan Perancangan Enterprise Architecture untuk Mendukung Fungsi Terkait System Online Payment Point Menggunakan Framewrok TOGAF ADM. Telkom University. Bandung

[6] Osvalds,G, 2011. Definition Of Enterprise Architecturecentric Models for The Systems Engineer. Eleventh Annual International Symposium of the International Council on Systems Engineering. Melbourne.

[7] The Open Group, 2011. ADM Overview TOGAF Version 9.1.The Open Group.

[8] Yunis, R., Surendro, K, 2008. Pemilihan Metodologi Pengembangan Enterprise Architecture untuk Indonesia. Prosiding SNIKA.Vol.3, No.1; pp A53-A59. Bandung.

[9] Sembiring, J., Nuryatno, E.T., and Gondokaryono, Y.S., 2011, Analyzing the Indicators and Requirements in Main Components of Enterprise Architecture
Methodology Development using Grounded Theory in Qualitative Methods, Society of Interdisciplinary Business Research Conference, Bangkok.

[10] Mardiansyah, C. R., 2012, Analisis dan Pengembangan Enterprise Architecture Menggunakan Framework TOGAF Pada Pengadilan Agama Bandug, Tugas Akhir Sistem Informasi Universitas Widyatama, Bandung.

[11] Rouhani, B. D., Mahrin, M. N., Nikpay, F., \& Nikfard,P. 2013. A Comparison Enterprise Architecture Implementation Methodologies. Kuala Lumpur.
30

Metrologi
Analisis dan Perancangan Enterprise Architecture Direktorat

Pada Fungsi Perencanaan dan Operasional Menggunakan Framework TOGAF ADM Nabila Mutiara, Rachmadita Andreswari, Ridha Hanafi (hal.22 - 30) 